\title{
Analisis Kinerja Operasional dan Kualitas Pelayanan PO. Mutiara Indah Murni dan PO. Widji Lestari pada Trayek Surabaya-Tuban
}

\author{
Amrita Winaya ${ }^{1}$, Theresia $\mathrm{MCA}^{2}$, Bimanda Maryudi $^{3}$ \\ 1,2,3 Jurusan Teknik Sipil, Fakultas Teknik Sipil dan Perencanaan, Institut Teknologi Adhi Tama, Surabaya \\ E-mail:amrita.winaya@itats.ac.id,longteyes@gmail.com
}

\begin{abstract}
ABSTRAK: Surabaya sebagai kota terbesar kedua di Indonesia dan sekaligus ibukota Provinsi Jawa Timur, menjadi magnet bagi para pendatang terutama yang berasal dari daerah-daerah di sekitarnya. Hal ini dapat meningkatkan pergerakan penduduk dari Kota Surabaya dan sebaliknya. Salah satunya adalah dari Surabaya menuju Tuban, kota-kota yang dilalui adalah Gresik, Lamongan, dan Bojonegoro. Untuk mengakomodasi pergerakan tersebut pemerintah selaku regulator bekerjasama dengan pihak swasta menyediakan sarana transportasi jalan raya berupa angkutan bus. Namun adakalanya terjadi kesenjangan jumlah penumpang antara satu perusahaan dengan perusahaan yang lain. Penelitian ini mengambil sampel dua buah perusahaan otobus (PO) yaitu PO. Mutiara Indah Murni dan PO. Widji Lestari. Instrumen yang digunakan pada pengumpulan data adalah kuesioner yang ditujukan bagi penumpang kedua PO tersebut. Untuk analisis menggunakan metode IPA atau Importance-Performance Analysis yang dapat mengukur tingkat kepentingan dan kinerja pelayanan. Dari hasil perhitungan dan analisis dapat diketahui bahwa faktor-faktor yang sangat berpengaruh terhadap pelayanan PO. Mutiara Indah Murni terdiri atas empat faktor yaitu keamanan, kenyamanan, waktu tempuh, dan kehandalan. Sedangkan faktor yang mempengaruhi kualitas pelayanan PO. Widji Lestari meliputi keamanan, kenyamanan, dan kehandalan. Dengan demikian PO. Widji Lestari lebih unggul dalam pelayanan apabila dibandingkan dengan PO. Mutiara Indah Murni yang masih memerlukan lebih banyak perbaikan dalam kualitas pelayanannya.
\end{abstract}

Kata Kunci : metode IPA, kualitas pelayanan, kinerja operasional bus

\section{PENDAHULUAN}

Sebagai kota terbesar kedua di Indonesia, Kota Surabaya memiliki jumlah penduduk yang cukup tinggi yaitu 2.765.000 jiwa berdasarkan data BPS tahun 2010. Dengan jumlah penduduk yang besar tersebut tentunya peluang pergerakan di dalam kota Surabaya maupun antara kota Surabaya dengan kota-kota-kota lainnya cukup tinggi. Salah satunya adalah pergerakan menuju Kota Tuban yang berjarak sekitar 103 kilometer dari Kota Surabaya. Dari Surabaya menuju Tuban melalui beberapa daerah yaitu Gresik, Lamongan, dan Bojonegoro, sehingga masyarakat yang menuju kota-kota tersebut dapat menggunakan moda transportasi dengan trayek Surabaya-Tuban.

Untuk mengakomodasi pergerakan tersebut, pemerintah selaku regulator dan fasilitator bekerjasama dengan pihak swasta dalam penyediaan sarana transportasi. Kerjasama ini salah satunya berupa Perusahaan Otobus (PO) yang menyediakan sarana angkutan jalan raya berupa bus, yang mana merupakan angkutan umum yang paling banyak digunakan oleh penumpang trayek Surabaya-Tuban.

Penggunaan jasa PO adakalanya tidak merata, dalam artian penumpang cenderung menggunakan PO yang sama sehingga PO yang lain menjadi sepi penumpang dan ada juga yang berhenti beroperasi. Oleh karena itu penulis melakukan penelitian mengenai kualitas pelayanan PO yang mempengaruhi pemerataan penumpang, yaitu pada PO. Mutiara Indah Murni dan PO. Widji Lestari. Kedua PO ini diambil sebagai sampel dan mempunyai titik keberangkatan yang sama yakni Terminal Osowilangun Surabaya dan titik kedatangan yang sama di Terminal Baru Tuban. Dari kedua PO ini akan dilakukan kajian mengenai kualitas pelayanan dan kinerja operasional menggunakan metode kuadran yaitu Importance Performance Analysis (IPA).

Tujuan dilakukannya penelitian ini meliputi dua hal yaitu mengidentifikasi variabel apa saja yang sangat mempengaruhi kualitas pelayanan masing-masing $\mathrm{PO}$, serta ingin mengetahui bagaimana kualitas pelayanan PO.
Mutiara Indah Murni dan PO. Widji Lestari terhadap penumpang bus, PO mana yang masih harus melakukan perbaikan terhadap kualitas pelayanannya.

\section{Metode Penelitian}

Sebelum pelaksanaan pengumpulan data, terlebih dahulu dilakukan tinjauan terhadap literatur yang bertujuan untuk memperoleh landasan teori dan dasar analisis yang terkait dengan penelitian. Beberapa diantaranya yaitu referensi mengenai perusahaan otobus, kualitas pelayanan angkutan umum, metode Importance Performance Analysis (IPA), serta kuesioner berupa skala likert.

Pada penelitian ini objek yang akan diteliti adalah Perusahaan Otobus atau disingkat PO, yang merupakan perusahaan penyedia angkutan darat untuk penumpang maupun barang berupa kendaraan bus (Nugroho, 2018).

Data primer yang diperlukan untuk penelitian ini meliputi jumlah penumpang PO. Mutiara Indah Murni dan PO. Widji Lestari, serta tingkat kepentingan dan kinerja pada aspek pelayanan masing-masing PO. Pengambilan sampel dilakukan dengan kuesioner menggunakan simple random sampling atau pengambilan sampel secara acak sederhana; sehingga setiap elemen populasi harus memiliki kesempatan yang sama untuk diambil sebagai sampel. Adapun pengambilan data jumlah penumpang dari masing-masing PO dilakukan selama satu minggu, sehingga berdasarkan teknik pengambilan sampel berupa Random Sampling dapat ditentukan jumlah sampel untuk PO. Mutiara Indah Murni adalah 23 orang, sedangkan jumlah sampel untuk PO. Widji Lestari adalah 33 orang.

Kuesioner merupakan instrumen atau alat pengukuran yang kemudian diuji validitas dan reliabilitasnya. Kuesioner tersebut dinyatakan valid apabila dapat mengukur suatu hal secara tepat seperti parameter yang hendak diukur (Rahmat, 2013). Sedangkan uji reliabilitas salah satunya dapat diukur menggunakan teknik Spearman Brown yang memiliki kriteria yaitu hanya tersedia dua pilihan jawaban untuk tiap pertanyaan, serta 
jumlah pertanyaan pada instrumen penelitian adalah genap (Siregar, 2017). Kuesioner yang diajukan kepada responden terdiri atas total 16 jumlah pertanyaan yang dikelompokkan menjadi delapan kategori atribut atau variabel pelayanan.

Menurut Rangkuti dalam Arifin (2015), salah satu alat analisis yang dapat digunakan untuk mengetahui kepuasan konsumen terhadap pelayanan jasa perusahaan adalah Importance-Performance Analysis (IPA). Pada metode ini dilakukan pengukuran tingkat kesesuaian untuk menentukan seberapa besar kepuasan pengguna jasa terhadap kinerja perusahaan, dan seberapa besar perusahaan sebagai penyedia jasa dapat memahami keinginan pelanggan (Nugraha dkk, 2014). Untuk melakukan analisis terhadap tingkat kepentingan dan kinerja suatu perusahaan, pada metode IPA dibuat matriks dua dimensi. Matriks ini membandingkan antara persepsi tingkat kepentingan konsumen yang mendorong penggunaan suatu produk atau pelayanan jasa (importance) dengan persepsi kepuasan konsumen terhadap kinerja produk atau jasa tersebut (performance). Perhitungan faktor-faktor kepentingan dan kinerja ini menggunakan nilai rata-rata dari hasil analisis kepentingan dan kinerja, sebagaimana dirumuskan pada formula di bawah ini:

$$
X=\frac{\sum_{i=1}^{n} X i}{n} \quad \text { dan } \quad Y=\frac{\sum_{i=1}^{n} Y i}{n}
$$

dengan:

$\mathrm{X}$ : nilai rata-rata tingkat kepuasan seluruh variabel

$\mathrm{Y}$ : nilai rata-rata tingkat kepentingan seluruh variabel

$\mathrm{X}_{\mathrm{i}}$ : nilai tingkat kepuasan variabel $\mathrm{i}$

$\mathrm{Y}_{\mathrm{i}}$ : nilai tingkat kepentingan variabel $\mathrm{i}$

$\mathrm{n}$ : jumlah responden

Kemudian selanjutnya adalah melakukan pengamatan atau observasi lapangan untuk menentukan waktu pelaksanaan survei. Dari observasi tersebut diperoleh waktu terpadat yaitu hari Sabtu pukul 10.00-14.00.

\section{Hasil dan Pembahasan}

Kuesioner yang telah disusun kemudian diuji validitasnya menggunakan rumus korelasi Product Moment, syaratnya adalah nilai $r$ hitung harus lebih besar daripada $\mathrm{r}$ tabel. Nilai $\mathrm{r}$ hitung dan $\mathrm{r}$ tabel adalah untuk masing-masing item pertanyaan. Apabila syarat tersebut telah dipenuhi, maka item pertanyaaan dinyatakan valid. Hasil dari perbandingan antara $r$ hitung dengan $r$ tabel ditunjukkan pada tabel 1 dan tabel 2, yang secara berurutan menggambarkan uji validitas kinerja dan uji validitas kepentingan PO. Mutiara Indah Murni.

Selain pengujian validitas, kuesioner juga perlu diuji reliabilitasnya, yang merupakan ketepatan atau akurasi dari alat ukur. Penilaian dilakukan dengan analisis statistik untuk mengetahui kesalahan ukur. Suatu instrumen atau alat ukur dikatakan reliabel jika instrumen tersebut cukup dipercaya untuk dijadikan sebagai alat ukur (Ong, 2014). Dalam uji reliabilitas ini dilakukan perhitungan menggunakan metode Spearman Brown. Hasil yang didapatkan yaitu dari 16 item pertanyaan kinerja dan kepentingan, yang diajukan ke responden PO. Mutiara Indah Murni maupun PO. Widji Lestari menunjukkan reliabilitasnya masuk kategori sangat tinggi. Kategori ini memiliki rentang nilai antara 0,800 sampai dengan 1,000 yang berarti item-item pertanyaan tersebut dinilai sangat konsisten pada hasilnya sehingga dapat dipergunakan secara berulangkali dalam periode waktu yang berbeda. Item pertanyaan masing-masing untuk kinerja dan kepentingan pelayanan sejumlah 16 tersebut dirangkum menjadi 8 kelompok variabel sebagaimana ditunjukkan pada tabel 1 dan tabel 2 berikut ini:

Tabel 1.Uji Validitas Kinerja PO.Mutiara Indah Murni

\begin{tabular}{lccc}
\hline $\begin{array}{l}\text { Variabel } \\
\text { Kinerja }\end{array}$ & r hitung & r tabel & Keterangan \\
\hline $\begin{array}{l}\text { 1.Kondisi fisik } \\
\text { kendaraan }\end{array}$ & 0,615 & 0,433 & Valid \\
\hline $\begin{array}{l}\text { 2. Ketersediaan } \\
\text { fasilitas tempat } \\
\text { duduk dan } \\
\text { kesesuaian } \\
\text { harga tiket }\end{array}$ & 0,538 & 0,433 & Valid \\
\hline $\begin{array}{l}\text { 3. Kebersihan } \\
\text { dalam } \\
\text { kendaraan }\end{array}$ & 0,489 & 0,433 & Valid \\
\hline $\begin{array}{l}\text { 4. Keamanan } \\
\text { dalam } \\
\text { kendaraan }\end{array}$ & 0,494 & 0,433 & Valid \\
\hline $\begin{array}{l}\text { 5. Pelayanan } \\
\text { petugas }\end{array}$ & 0,553 & 0,433 & Valid \\
\hline 6. Kenyamanan & 0,600 & 0,433 & Valid \\
\hline $\begin{array}{l}\text { 7. Waktu } \\
\text { Tempuh }\end{array}$ & 0,517 & 0,433 & Valid \\
\hline 8. Kehandalan & 0,555 & 0,433 & Valid \\
\hline
\end{tabular}

Tabel 1 merupakan variabel pelayanan untuk kinerja pada PO. Mutiara Indah, dari perbandingan $r$ tabel dengan $r$ hitung diperoleh hasil yang valid untuk semua item pertanyaannya. Nilai $r$ tabel untuk segi kepentingan maupun segi kinerja adalah sebesar 0,433. Setelah dilakukan perhitungan terhadap $r$ hitung untuk uji validitas kepentingan PO. Mutiara Indah, didapatkan hasil yang juga valid untuk keseluruhan pertanyaan pada variabelnya, yaitu dapat dilihat pada tabel 2 berikut ini:

Tabel 2. Uji Validitas Kepentingan PO.Mutiara Indah Murni

\begin{tabular}{lccc}
\hline $\begin{array}{l}\text { Variabel } \\
\text { Kepentingan }\end{array}$ & r hitung & r tabel & Keterangan \\
\hline $\begin{array}{l}\text { 1.Kondisi fisik } \\
\text { kendaraan }\end{array}$ & 0,548 & 0,433 & Valid \\
\hline $\begin{array}{l}\text { 2. Ketersediaan } \\
\text { fasilitas tempat } \\
\text { duduk dan } \\
\text { kesesuaian } \\
\text { harga tiket }\end{array}$ & 0,564 & 0,433 & Valid \\
\hline $\begin{array}{l}\text { 3. Kebersihan } \\
\text { dalam } \\
\text { kendaraan }\end{array}$ & 0,486 & 0,433 & Valid \\
\hline $\begin{array}{l}\text { 4.Keamanan } \\
\text { dalam } \\
\text { kendaraan }\end{array}$ & 0,524 & 0,433 & Valid \\
\hline $\begin{array}{l}\text { 5. Pelayanan } \\
\text { petugas }\end{array}$ & 0,516 & 0,433 & Valid \\
\hline
\end{tabular}




\begin{tabular}{lccc}
\hline $\begin{array}{l}\text { Variabel } \\
\text { Kepentingan }\end{array}$ & r hitung & r tabel & Keterangan \\
\hline 6. Kenyamanan & 0,527 & 0,433 & Valid \\
\hline $\begin{array}{l}\text { 7. Waktu } \\
\text { Tempuh }\end{array}$ & 0,495 & 0,433 & Valid \\
\hline 8. Kehandalan & 0,463 & 0,433 & Valid \\
\hline
\end{tabular}

Untuk uji validitas segi kinerja dan kepentingan PO. Widji Lestari ditampilkan pada tabel 3 dan tabel 4 di bawah ini:

Tabel 3. Uji Validitas Kinerja PO. Widji Lestari

\begin{tabular}{lccc}
\hline Variabel Kinerja & $\begin{array}{c}\mathbf{r} \\
\text { hitung }\end{array}$ & $\begin{array}{c}\mathbf{r} \\
\text { tabel }\end{array}$ & Keterangan \\
\hline $\begin{array}{l}\text { 1.Kondisi fisik } \\
\text { kendaraan }\end{array}$ & 0,566 & 0,355 & Valid \\
\hline $\begin{array}{l}\text { 2. Ketersediaan } \\
\text { fasilitas tempat duduk } \\
\text { dan kesesuaian harga } \\
\text { tiket }\end{array}$ & 0,458 & 0,355 & Valid \\
\hline $\begin{array}{l}\text { 3. Kebersihan dalam } \\
\text { kendaraan }\end{array}$ & 0,586 & 0,355 & Valid \\
\hline $\begin{array}{l}\text { 4. Keamanan dalam } \\
\text { kendaraan }\end{array}$ & 0,569 & 0,355 & Valid \\
\hline 5.Pelayanan petugas & 0,728 & 0,355 & Valid \\
\hline 6. Kenyamanan & 0,482 & 0,355 & Valid \\
\hline 7. Waktu Tempuh & 0,625 & 0,355 & Valid \\
\hline 8. Kehandalan & 0,569 & 0,355 & Valid \\
\hline
\end{tabular}

Dari hasil perhitungan nilai r untuk segi kinerja PO. Widji Lestari, dapat diketahui bahwa semua item pertanyaannya adalah valid, yang ditunjukkan dengan nilai $r$ hitung yang lebih besar daripada nilai $r$ tabel. Untuk segi kepentingan juga diperoleh nilai $r$ hitung yang lebih besar daripada nilai $r$ tabel, sehingga semua item pertanyaan pada segi kinerja dan kepentingan PO. Widji Lestari dinyatakan valid.

Tabel 4. Uji Validitas Kepentingan PO. Widji Lestari

\begin{tabular}{lccc}
\hline $\begin{array}{l}\text { Variabel } \\
\text { Kepentingan }\end{array}$ & $\begin{array}{c}\mathbf{r} \\
\text { hitung }\end{array}$ & $\begin{array}{c}\mathbf{r} \\
\text { tabel }\end{array}$ & Keterangan \\
\hline $\begin{array}{l}\text { 1.Kondisi fisik } \\
\text { kendaraan }\end{array}$ & 0,714 & 0,355 & Valid \\
\hline $\begin{array}{l}\text { 2. Ketersediaan } \\
\text { fasilitas tempat duduk } \\
\text { dan kesesuaian harga } \\
\text { tiket }\end{array}$ & 0,642 & 0,355 & Valid \\
\hline $\begin{array}{l}\text { 3. Kebersihan dalam } \\
\text { kendaraan }\end{array}$ & 0,700 & 0,355 & Valid \\
\hline $\begin{array}{l}\text { 4.Keamanan dalam } \\
\text { kendaraan }\end{array}$ & 0,639 & 0,355 & Valid \\
\hline 5.Pelayanan petugas & 0,794 & 0,355 & Valid \\
\hline 6. Kenyamanan & 0,534 & 0,355 & Valid \\
\hline 7. Waktu Tempuh & 0,679 & 0,355 & Valid \\
\hline 8. Kehandalan & 0,612 & 0,355 & Valid \\
\hline
\end{tabular}

Setelah dilakukan uji validitas dan uji reliabilitas kuesioner, analisis selanjutnya adalah pada penilaian masing-masing variabel aspek pelayanan dengan menggunakan metode IPA. Pada metode tersebut, responden diminta melakukan penilaian terhadap tingkat kepentingan dan kinerja untuk aspek pelayanan bus, yang digambarkan pada diagram kartesius dimana sumbu X menunjukkan kinerja sedangkan sumbu $\mathrm{Y}$ adalah kepentingan. Gambar 1 adalah hasil perhitungan dari aspek kinerja dan kepentingan pada PO. Mutiara Indah Murni.

Kuadran A yang terletak di kiri atas adalah prioritas utama (concentrate here), jika dilihat dari sisi kepentingan konsumen maka variabel pelayanan bus berada pada tingkat yang tinggi. Namun dari kepuasannya, konsumen

merasakan tingkat yang rendah sehingga menuntut perbaikan variabel pelayanan sebaik mungkin. Variabelvariabel yang termasuk dalam kuadran A ini meliputi tersedianya fasilitas keamanan, kenyamanan berupa fasilitas pendingin (AC) di dalam kendaraan, waktu tempuh, jadwal keberangkatan, dan jadwal kedatangan.

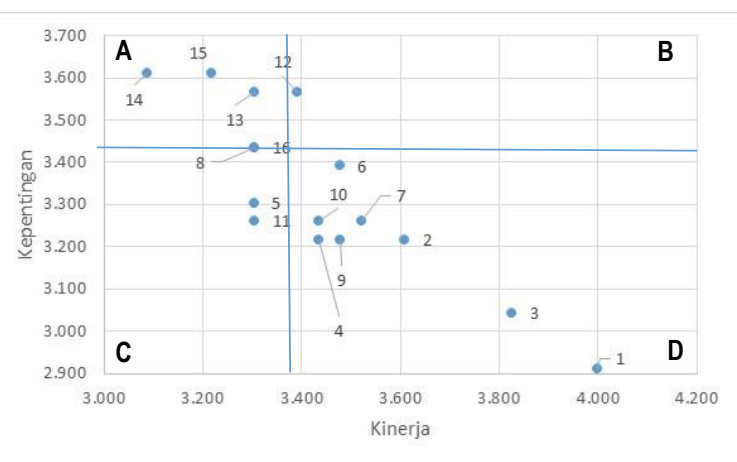

Gambar 1. Diagram Kartesius IPA untuk PO. Mutiara Indah Murni

Sedangkan kuadran B di kanan atas menggambarkan pertahankan prestasi (keep up the good work) yakni jika ditinjau dari segi kepentingan maupun kepuasan konsumen, variabel-variabel yang termasuk dalam kuadran ini berada pada tingkat yang tinggi. Dengan demikian, perusahaan dapat mempertahankan prestasinya yaitu tanpa diharuskan ada perbaikan kualitas karena variabel-variabelnya yang cukup menarik bagi konsumen, namun tetap dilakukan pengelolaan pelayanan dengan baik. Variabel-variabel dalam kuadran B ini yaitu kebersihan di dalam kendaraan dan tersedianya fasilitas kebersihan.

Untuk kuadran C yang berada di sisi kiri bawah merupakan prioritas rendah (low priority), dimana jika dilihat dari kepentingan konsumen maka variabel pelayanan dianggap tidak terlalu penting, dan dari kepuasan pelanggan juga tergolong kurang baik. Pada kuadran ini konsumen cenderung mengabaikan variabel pelayanan yang ada, akan tetapi lain halnya dengan PO. Mutiara Indah Murni yang sebaiknya perlu mewaspadai variabel pada kuadran ini karena tingkat kepentingan pengguna bus dapat berubah seiring dengan peningkatan kebutuhan. Variabel-variabel tersebut terdiri atas ketersediaan fasilitas, kebersihan, pelayanan petugas, dan kenyamanan tempat duduk di dalam kendaraan. 
Pada bagian kanan bawah terdapat kuadran D yaitu faktor-faktor yang dianggap tidak terlalu penting dan tidak diharapkan oleh pengguna jasa. Atau dengan kata lain, konsumen atau pengguna jasa sudah cukup puas dengan pelayanan yang disediakan, sehingga PO. Mutiara Indah Murni tidak perlu melakukan perbaikan pelayanan pada kuadran ini. Variabel-variabel pada kuadran ini mencakup kondisi fisik di dalam maupun di luar kendaraan, ketersediaan fasilitas tempat duduk yang mencukupi, tingka keamanan di dalam bus, dan pelayanan petugas yaitu kemampuan pengemudi dalam berkendara.

Untuk segi kepentingan dan kinerja pelayanan dari PO. Widji Lestari dapat dilihat pada Gambar 2. Hasil perhitungan aspek pelayanan untuk PO. Widji Lestari pada kuadran A menggambarkan bahwa pada variabel ketersediaan fasilitas keamanan, kenyamanan penumpang yang berupa berfungsinya fasilitas pendingin ruangan, serta kehandalan yang meliputi ketepatan jadwal keberangkatan dan kedatangan, konsumen merasakan tingkat kepuasan yang rendah. Akibatnya konsumen menuntut perbaikan pelayanan pada variabel-variabel tersebut. Oleh karena itu PO. Widji Lestari selaku operator dan penyedia layanan perlu melakukan perbaikan secara menyeluruh agar kepuasan pengguna jasa terhadap variabel-variabel pada kuadran ini dapat dipenuhi.

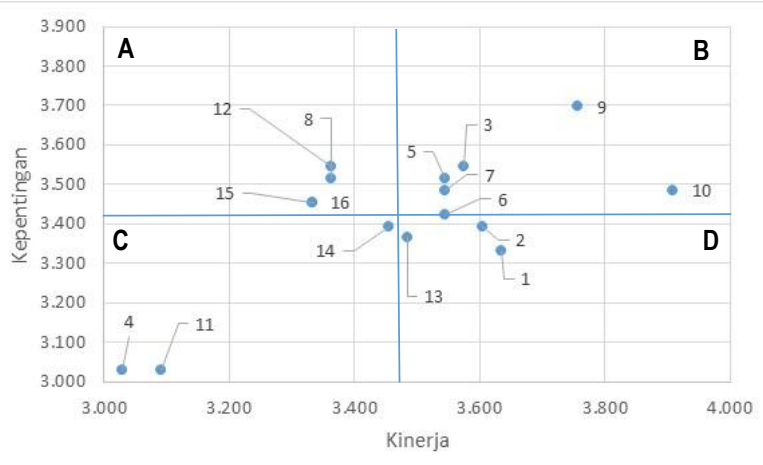

Gambar 2. Diagram Kartesius IPA untuk PO. Widji Lestari

Sementara itu pada kuadran B, perusahaan cukup mempertahankan kualitas pelayanannya dengan tetap mengusahakan pengelolaan jasa sebaik-baiknya. Variabel-variabel pelayanan pada kuadran ini tidak perlu diperbaiki, karena telah dapat menarik kepuasan konsumen. Aspek pelayanan yang termasuk dalam kuadran B ini yaitu ketersediaan fasilitas tempat duduk penumpang yang mencukupi, faktor kebersihan yakni kesadaran penumpang dan awak bus terkait kebersihan di dalam kendaraan dan tersedianya fasilitas kebersihan, tingkat keamanan bus, serta pelayanan petugas yang mencakup kemampuan pengemudi dan pelayanan kondektur yang ramah.

Pada posisi kuadran $\mathrm{C}$, aspek pelayanan yang masuk ke dalam kuadran ini adalah kesesuaian tarif dengan kualitas pelayanan, kenyamanan, dan waktu tempuh. Kenyamanan pada kuadran $\mathrm{C}$ ini adalah fasilitas tempat duduk yang nyaman. Jika dilihat dari kepuasan konsumen, variabel aspek pelayanan yang ada di kuadran ini dianggap tidak terlalu penting dan dari kepuasan pengguna juga kurang baik. Dengan demikian, PO. Widji
Lestari perlu mewaspadai variabel aspek pelayanan pada kuadran ini karena tingkat kepentingan konsumen dapat berubah seiring meningkatnya kebutuhan.

Untuk kuadran D dapat diketahui bahwa jika dilihat dari kepentingan pengguna jasa, variabel pelayanan yang ada di kuadran ini dianggap kurang penting, walaupun secara kepuasan konsumen sudah cukup tinggi. PO. Widji Lestari tidak perlu melakukan perbaikan karena untuk mencegah terjadinya pemborosan. Adapun variabelvariabel pelayanan yang termasuk dalam kuadran D ini terdiri atas kondisi fisik baik di dalam maupun di luar kendaraan, serta ketepatan waktu tempuh.

\section{Kesimpulan}

Berdasarkan hasil analisis data dapat diambil kesimpulan pada penelitian ini, yaitu terdapat beberapa variabel yang sangat berpengaruh terhadap pelayanan masing-masing PO. Untuk PO. Mutiara Indah Murni, variabel-variabel yang mempengaruhi kualitas pelayanan adalah keamanan, kenyamanan, waktu tempuh, dan kehandalan. Sedangkan untuk PO. Widji Lestari beberapa variabel yang berpengaruh terhadap kualitas pelayanan terdiri dari keamanan, kenyamanan, dan kehandalan. Variabel-variabel yang mempengaruhi kualitas pelayanan adalah yang termasuk dalam kuadran A, yaitu merupakan aspek pelayanan yang kurang baik dan mendapatkan prioritas utama dalam perbaikan kinerjanya.

Penilaian kualitas pelayanan yang diberikan oleh PO. Widji Lestari lebih baik daripada pelayanan oleh PO. Mutiara Indah Murni. Penumpang cenderung menggunakan jasa pelayanan bus dari PO. Widji Lestari dibandingkan dengan PO. Mutiara Indah Murni. Hal ini dapat diketahui dari variabel aspek pelayanan pada PO. Mutiara Indah Murni yang memerlukan lebih banyak perbaikan.

\section{Daftar Pustaka}

Arifin, Samsul Andy., Sulistyo, Harnen., Djakfar, Ludfi. (2015), Kajian Kepuasan Penumpang Terhadap Kinerja Pelayanan Maskapai Penerbangan Rute Surabaya-Jakarta (Studi Kasus: Bandar Udara Internasional Juanda Surabaya), Jurnal Tata Kota dan Daerah, Volume 7 No.1.

Nugraha, Rizal., Harsono, Ambar., Adianto, Hari. (2014), Usulan Peningkatan Kualitas Pelayanan Jasa pada Bengkel " $X$ " Berdasarkan Hasil Matrix ImportancePerformance Analysis (Studi Kasus di Bengkel AHASS PD.Sumber Motor Karawang), Reka Integra Jurnal Online Institut Teknologi Nasional.

Nugroho, Bimanda Maryudi. (2018). Analisis Kualitas Pelayanan PO. Mutiara Indah Murni dan PO. Widji Lestari Terhadap Daya Pilih Responden Pada Trayek Surabaya-Tuban Dengan Titik Keberangkatan Terminal Osowilangun dan Titik Kedatangan Terminal Baru Tuban, Skripsi Tidak Diterbitkan, Institut Teknologi Adhi Tama, Surabaya.

Ong, Johan Oscar., Pambudi, Jati. (2014), Analisis Kepuasan Pelanggan dengan Importance Performance Analysis di SBU Laboratory Cibitung PT.Sucofindo (Persero), Jati Undip Vol.IX No.1.

Rahmat, Dr.H.Msi. (2013), Statistika Penelitian, CV.Pustaka Setia, Bandung. 
Siregar, Sofyan. (2017), Statistik Parametrik Untuk Penelitian Kuantitatif, Dilengkapi dengan Perhitungan Manual dan Aplikasi SPSS Versi 2017, Bumi Aksara, Jakarta. 
Jurnal Rekayasa Tenik Sipil Universitas Madura Vol. 4 No.2 Desember 2018 ISSN 2527-5542

Halaman Sengaja Dikosongkan 